\title{
FRAGMENTED STATES AND INTERNATIONAL RULES OF LAW
}

\author{
Sol Picciotto
}

Lancaster University, U.K.

Published in (1997) Social and Legal Studies 6(2): 259-279.

\begin{abstract}
Globalisation, as the latest phase in the development of the world system, involves a fragmentation and restructuring of state forms, in which law is being called upon to mediate shifts in the structures of power. A historical and empirically rich analysis is needed to help understand the nature and changing forms of statehood, as well as the possibilities and limits of law, and the paper explores these in the context of some aspects of business regulation, especially income taxation.
\end{abstract}

\section{Globalisation and State Fragmentation}

In 1995, the UK's Economic and Social Research Council identified and publicised three main 'thematic priorities': globalisation, regulation and governance, and social integration and exclusion. Both the selection of these topics, and the way in which they have been expressed, are very revealing of much current public discussion. The issues themselves are far from new, indeed I myself have been concerned with all three during most of my academic life. ${ }^{1}$ However, in current discussions they appear under new and modish guises: now we have the concept of globalisation, replacing internationalisation; governance, instead of government or the state; and social integration and exclusion, instead of class, race and gender. The newer terms are, I think, rather more fuzzy and elusive about the nature of the social processes to which they refer. The inflection results, I think, partly from changes in the character of those processes, but more significantly, from new ways of perceiving and shaping those processes. Not surprisingly, there is considerable debate and contestation about all three.

Many are ambivalent about the current fashionable discussions of globalisation. Has there really been such a transformation of international interactions, resulting in a global homogenisation of social and cultural life, as the term suggests? Why has the concept become so popular in both academic and everyday discussions? In some cases, it seems to result from an abrupt awareness that common assumptions about our social world are no longer valid, without too much inquiry about how far they ever were: a realisation that we don't just live in and can't just study a society, a single legal system, or a national state, and that the world contains a multiplicity of diverse and interacting societies, states, and legalities. But if this is the case, why the term globalisation, which misleadingly suggests an increasing global homogeneity, rather than awareness of diversity or interconnectedness, as I think internationalisation does?

In another perspective, globalisation debates seem to result from post-Cold War concerns, to envisage and construct a New World Order, which might be more cohesive and coordinated than was previously possible. Yet if globalisation is about 
projects to improve or rationalise world government, actual proposals along these lines do not seem to have much popular resonance. I think this was shown, for instance, by the resounding silence which met the Report on Global Governance produced recently by a group of eminent statespeople, which put forward proposals for far-reaching reforms of the United Nations system and international organisation generally (Commission on Global Governance 1995). Equally, we have only to consider the wide-ranging opposition which seems to have grown, at least since the signing at Maastricht of the Treaty on European Union, against any idea that we might need a European super-state to govern the Single European Market.

Rather, what seems to have gone global is The Market, or at least ideologies of free trade and open markets. Yet even here things are not quite as they seem. Globalisation is generally said to involve an increasing volume or velocity of international flows, in economic terms of trade, investment, and finance, in cultural terms of artefacts, signs and symbols. Certainly, globalisation could be said to have 'given a cosmopolitan character to production and consumption in every country', so that 'in place of the old local and national seclusion and self-sufficiency, we have intercourse in every direction, universal inter-dependence of nations'. Yet those are quotations from the description of the creation of the world market given almost 150 years ago in 1848 by Karl Marx and Friedrich Engels in The Manifesto of the Communist Party. While the nature of the world economy has greatly changed since then, it is not obvious that there has been any substantial increase in the degree of what they already at that time described as 'the universal inter-dependence of nations'. Attempts to quantify the growth of international transactions over the past century or more, at least when calculated in proportion to local or national transactions, do not generally show a significant relative increase. ${ }^{2}$

What seems to be more important is the increased potential for such flows, resulting from the reduction or elimination of national and local barriers to all kinds of trade and investment. The gradual reduction of tariff barriers and elimination of exchange controls during the 1960s and 1970s widened during the 1980s into a more generalised drive towards national deregulation, opening up all kinds of markets to access from outside. Thus, what has been increasingly created is a network of globally interlinked although still in many ways very locally based markets. However, when looked at more closely, there has been as much re-regulation as de-regulation, and often the new regulatory systems have originated in global arenas and have been imported into national law. A dramatic example is provided by financial markets, where the breaking-down of relatively closed national systems of credit and finance has been accompanied and facilitated by elaborate new regulatory arrangements, developed through complex international political processes. The result has been a raft of Brussels directives and Basle guidelines, which have introduced formalised rules and professionalised supervision in place of cosy clubs and informal oversight by central banks and finance ministries (Porter 1993, Kapstein 1994, Goldstein et al 1992, Fishman 1993).

This has involved some intriguing shifts in the character of regulation, away from command-and-control through the state, and towards functionalist modes of governance based on the construction of new professional regulatory cultures by accountants, lawyers, and managers. The privatisation of the state has been a general 
global trend: in Britain it now extends beyond utilities such as water or electricity, and even the raising of money for public projects is being done through the National Lottery (though this idea is not entirely new, even in England: historians tell us that William of Orange had an early hit with the Million Lottery of 1694). The new managerialism of the 'audit society' has even spread to venerable institutions such as universities, as we academics are well aware. These new forms of regulation are designed to enable such social activities and institutions to operate in an environment of global competition, while attempting to define conditions which might ensure both private profit and the fulfilment of public functions (not always very successfully, as seen currently in situations as diverse as the controversy over the National Lottery, and the financial crisis of the Channel Tunnel). At the same time, the term 'governance' is also used to signify the provision of public order, protection of private property, but not necessarily liberal democracy, to required global standards by countries, especially in eastern Europe and Africa, as a condition of political support and economic investment from the West (Faundez 1996).

In this perspective, globalisation entails a process of fragmentation. In particular, in place of centralised government primarily through national states, we have moved to delegated forms of governance operating in layers within and across states. Here we find the significance of the second of the ESRC's themes. It is in this context that I believe we should consider the often-cited question of the future of the nation-state and the international state system. By the term fragmentation, I would like to suggest a contested process of destabilisation and restructuring, involving a search for new forms of synthesis between the economic and political aspects of social relations, rather than a deterministic tendency for economic pressures from an already-existing world market to undermine otherwise stable political structures. In fact, economic activities are deeply embedded in social, cultural, and normative practices.

Here I think we come to the third of the ESRC's priority themes: social integration and exclusion. Clearly, there has been increasing concern that global competitive forces tend to exacerbate existing social differences while also creating new forms of exclusion. More broadly, if globalisation entails a process of fragmentation of the public sphere, there must be concern about its effects on the institutions of liberal democracy. This I think is the sub-text of the fears about the threats to the national democratic state from global free trade, expressed by commentators and politicians both of the Left and the Right. But this is to see the threat to our institutions and way of life as coming from outside, deflecting attention away from internal failures. The term state fragmentation might bring to mind the dramatic breakdowns of other states such as Yugoslavia or Rwanda, but we should not forget that even we in this United Kingdom have signally failed to resolve the long-running problem of Northern Ireland. And if we are tempted to attribute such problems to ancient ethnic rivalries, we should remember that national identities are not simply inherited but constructed, and that the mythology of national identity in the liberal state depends significantly on acceptance that it can deliver social justice. Hostility to foreigners is powered by fear that They will take over Our jobs, Our homes, and Our institutions. 


\section{RECONSTRUCTING INTERNATIONAL LEGALITY}

These changes provide a rich and challenging context for an international lawyer. In the current period of ferment, reconceptualisation, and restructuring of the world system, it is not surprising that law is being called upon to play an increasingly important role in mediating the shifting structures of power. Too often, however, resort to law seems due to the failure of politics. In particular, there is increasingly frequent recourse to international law as a remedy for the failure or inadequacies of the nation-state. Notably, David Held has recently outlined a blueprint for a 'cosmopolitan democracy' as a response to the threats to liberal democracy and the national state posed by globalisation (Held 1995). Essentially, this seems to be an argument for a neo-liberal form of global government, central to which is a stronger role for international law. Although these are in some ways ambitious proposals, they are surprisingly uncritical of the capacity of international law to help relieve the pressures on the state system resulting from the major crises of the global political economy. In contrast, one of the foremost contemporary critics of international law has argued that the international system exists only as a shared vocabulary and institutional practices, and that 'as long as there is no wide agreement on what constitutes the good life, the formality of statehood remains the best guarantee we have against the conquest of modernism's liberal aspect by modernism's authoritarian impulse' (Koskenniemi 1991, 397).

International lawyers are familiar enough with the corridors of diplomacy that normally their proposals for a strengthening of world law are tempered with a dose of political realism. This tends, however, to result in a mutually-reinforcing formalism. For example, James Crawford in his inaugural lecture at Cambridge chose the topic Democracy and International Law (Crawford 1994; cf Franck 1992). Interestingly, however, his theme was the extent to which international law contains or should develop some minimum principles for national democracy, and not at all what I think is the more important aspect of the issue, the lack of democracy in the international sphere and hence the fundamental problem of lack of legitimacy of international law itself.

To understand something of the possibilities and limits of law in the current world system, we need first of all a critical evaluation both of statehood and of international law, and of how they have developed historically. Certainly, the key institution of the international system of liberal capitalism is the national state, yet its character is too often taken for granted. Especially enigmatic is the simultaneously national and international form of the modern state. ${ }^{3}$ In what follows I will try to probe some of the contradictions and limits of the present-day process of reconstruction of international legality, within such a broader historical and critical perspective.

\section{SOVEREIGNTY AND STATEHOOD}

The central conundrum for international law, as for politics, is state sovereignty. Sovereignty is generally recognised as posing a major obstacle for any general reconceptualisation of international law, yet it seems hard to dislodge from its place as the conceptual cornerstone of modern international law, indeed of global law as a whole. Take away state sovereignty and instead of a clear hierarchy of legal orders there would be only a bewildering variety of legalities jostling and competing for 
acceptance. Thus, it is perhaps not surprising that contemporary international lawyers, even those taking a 'critical' perspective, are deeply divided and ambivalent about the importance of statehood and sovereignty (see Picciotto 1996). But much depends on how sovereignty itself is understood.

The notion of supreme or untrammelled power embodied in the concept of sovereignty has two aspects, internal and external. In the modern, post-Napoleonic state system, each state claims the monopoly of legitimate power over its subjects, since the overt elements of coercive power have been removed from personal relations and vested in autonomised institutions with a public character. Internally, the state asserts a monopoly on coercive force. Although other normative orders can be tolerated, or even encouraged by delegation to self-regulating associations or institutions, they are subject to the over-riding authority of state law, which alone can validate coercive sanctions. ${ }^{4}$ State sovereignty can be, and often is, despotic; but within the liberal state it is legitimised by the rule of law. Government through the rule of law claims to guarantee the formal equality and freedom of all legal subjects and to facilitate free economic exchange, through institutions, processes and concepts based on abstract and universalist principles of fairness and justice.

However, much of the work of critical lawyers is concerned to deconstruct this world of formalist law in various ways, and to show that there is a gulf between the formalistic principles and universalist pretensions of law which offer visions of justice based on abstract notions of individual autonomy, equality and freedom, and the dense and particular social contexts and experiences of real people. Law at best can provide a framework to test, evaluate, and adjudicate competing claims of right. The promise it holds out of governing social relations by providing an independent and neutral basis of predictability and rationality, tends to evaporate when its abstract principles are actually operationalised. At this point we find that the substantive content of decisions must more or less covertly be supplied from political, economic, or ethical considerations. Although critics of the liberal conception of the rule of law are sometimes treated as dangerous radicals, I think the aim of a critical approach is to probe the limits of law, so that it can be transcended, not abandoned; and, in particular, to point out, as non-lawyers already know in their hearts, that law alone is incapable of ensuring a fair and just society. Indeed, to move towards such a society we need to develop new understandings, principles, and institutions of legality, and even to transcend our present concepts of legality altogether and integrate them at a higher plane. So much, for now, for the internal aspects of sovereignty and the rule of law.

Externally it is states themselves that are free and equal legal subjects, and this seems at first sight to replicate the internal realm of the state. However, the external aspect of sovereignty means that states themselves are not subject to any higher authority, so they interact formally as equals in a community of a different order and on a higher plane than the national. For some varieties of legal formalism, this creates serious doubt as to whether there can be any international law worth the name. Most people can agree that it is law, but one of a different kind, based on principles and obligations freely accepted as binding by its sovereign state subjects. Thus, international legal obligations are grounded in the mutual self-interest of states, each pursuing what it considers to be its national interest, but bound together within an 
overarching normative order. The lack of centralised institutions with overriding coercive powers is said by some to indicate the 'primitive' nature of the international legal system, while others assert that on the contrary the relatively orderly interaction of states without the need for a higher authority shows the effectiveness of international law as a self-regulatory system.

Yet while the state is clearly an important focus of identity and locus of power, what seems very unsatisfactory is the personification of the state which turns it into the 'subject' of international law, and conceptualises the international state system as a 'community of states'. By ignoring the social relations on which statehood is built, this makes it hard to understand either the internal or external role of states. It also produces a picture of states as autonomous and compartmentalised units, each governing only its own citizens, whereas even cursory study shows that private economic and social relations cross state boundaries and are therefore governed by multiple and often overlapping jurisdictions.

Thus, sovereignty should be seen as a particular way of distributing political power, within and between states. The fiction of unlimited internal sovereignty is complemented and sustained by its corollary, the sovereign equality of states. The exercise of power is legitimated within the state by the generation of consensus around the national common interest. Internationally, formally equal sovereigns bargain on the basis of the national interest of each for reciprocal benefits or to secure mutual or common interests.

Although the principle of state sovereignty appears to establish a clear structure or order in the international system, it rests on a shifting foundation, which continually produces fault lines. The existence and continued dynamic of accumulation through the world market continually reshapes the interdependent or interconnected character of social and economic activities. At the same time, the uneven and unequal patterns of accumulation create substantive political and economic inequalities which undermine the formal principle of sovereign equality. Thus, state sovereignty is not an impermeable barrier but a fluid point of articulation between the international and the domestic sphere. Furthermore, its character shifts and is contested, as can be seen by the controversies among international lawyers and the changes in many of the key principles of international law. If the 19th century was the high-water mark of statist conceptions of international law, universalist perspectives have gathered momentum during the present century.

The state-centred view emphasises the autonomy and sovereignty of the nation-state, and therefore insists on a strict dualism between international and national law. Statism is reluctant to accept that international legal obligations restrict state autonomy unless very clearly emerging from the "consent" of sovereign states. It seeks to maintain a strict compartmentalisation of legal orders, the borders between national and international law being patrolled by national governments on behalf of the state.

Universalism, on the other hand, sees a continuity between international and national law, which gives individuals and other legal entities more direct access to the international sphere, demoting governments from any position of primacy. It emphasises, for example, that national courts are not only authoritative in their own 
sphere, but also contribute to the development of international law principles, and equally that rights and obligations under international law can be invoked in cases under national law where appropriate. Thus, for example, there has been a dilution of principles such as state immunity, which makes it possible for national courts and lawyers to become involved more directly in many issues previously dealt with on an inter-state basis. Conversely, rules agreed on an inter-state level can become national law, often automatically. The most striking example of this is the direct applicability and direct effect of EC law, developed in the forthright jurisprudence of the European Court of Justice; but in addition, a high proportion of changes in national law result more or less directly from international agreements. Although EC law is generally referred to as 'supranational', it still seems hard to discuss the implications of the greater interpenetration of national and international law without using the term 'sovereignty'.

Universalism therefore sees an intermingling of the rights and duties of states and of other legal subjects, both individuals and corporations. From this perspective global legal régimes come into view, covering matters as diverse as human rights, the protection of the natural environment, and international business or commercial activities. These involve an intermingling of public and private actors, in national and international forums. Certainly, many examples can be found demonstrating trends towards what might be called a 'globalisation' of legal régimes covering matters of international concern.

However, when looked at more closely these trends are not quite as they are represented in some of the recent globalisation debates. First, they have a much longer history than is often appreciated, often going back a century or more. Secondly, it is generally not a matter of issues previously dealt with nationally somehow bursting their bounds and breaking into the global arena, but rather a process of breakdown and restructuring of the articulation between the national and the international. ${ }^{5}$ Thirdly, and most importantly, the fragmentation of state sovereignty produces a much more complex and layered interaction of regulatory arrangements of various kinds, which may entail dissonance rather than the harmonious coordination suggested by the term 'régime'.

In this context of fragmentation, it is not surprising that law and lawyers might play an increased role. Since law links the apparently autonomous spheres of politics and economics, lawyers are accustomed to mediating not only between the public sphere of the state and the private sphere of economic and personal relations, but also between different public spheres. The lawyer-diplomat has the advantage of having no 'national' allegiance except to the intellectual capital invested in mastering the language and techniques deployed in the fields in which she or he is active, unlike the state official or politician whose duty is to the national interest. ${ }^{6}$ Although legal systems are deeply rooted in particular cultural traditions going back over centuries, there has been considerable interaction and mutual influence. Even the staunchly pragmatic common law has had its Romanist influences, and there has been wholesale importation of codes of law not only in colonial contexts, but also by countries such as Japan. 
Thus, there is a long historical tradition of the cosmopolitan or comparative lawyer, working at the interface between different legal orders. Moreover, lawyers perhaps have the advantage that although they speak fundamentally the same language of fairness, justice, and order, it has many dialects and variations. Thus, the task of the international or comparative lawyer is not to homogenise, or create a legal Esperanto, but to interpret one to the other, evaluate differences, facilitate interactions. Unlike economists, whose aim seems to be to subject us all to the same iron laws of market efficiency, lawyers seem to offer the prospect of preserving particularity while facilitating consensus. Yet, as I have said, this promise may all too often prove illusory. At the end of the day, law is binary: one party is right, the other is wrong; compensation must be paid, punishment administered; the only consistent winner in the game is the lawyer.

\section{THE INTERNATIONALISATION OF BUSINESS TAXATION}

Next, I will briefly illustrate some of these issues by taking some examples from my general field of research, the internationalisation of business regulation, and especially the area that recently occupied me for several years, international taxation. Although commonly regarded a dry and technical subject, I found the story of how the international arrangements for income taxation were constructed to be a fascinating one, which reveals much about the changing nature of the state in the international system. Taxation is after all a central nexus in the relation between state and citizen, since without it there would be no collectivity. Taxation has a changing form, reflecting and moulding social changes: thus an important part of the crisis of the nation-state today is its fiscal crisis. A key element of the consolidation of the modern liberal welfare-warfare state, as a national state within an international system, was the shift to a broad basis of taxation based on income, which became generally established in the first decade or two of this century. ${ }^{7}$

The basis of legitimacy of income taxation is the principle that it applies equally to all citizens, although this still leaves considerable room for dispute about what constitutes fair treatment if incomes are unequal. So there have been recurring debates both about the minimum level of taxable income or tax threshold, and about graduated rates on higher levels of income as against a single flat-rate (this has been recently revived, especially in the USA). The income tax became an efficient mass tax in developed capitalist countries with the introduction of deduction at source, especially on employment income, which came at the time of the Second World War. Government revenues in capitalist welfare states became increasingly dependent on employment income, not least because other types of income offer greater opportunities for tax planning or avoidance. Tax planning entails using the flexibility within legal definitions to alter the characterisation of an income flow, or to redirect it or shift its timing. Such practices can be legitimised as embodying the right of each individual freely to dispose of property, although in reality they become constituted as an almost routinised game played between accountants, lawyers and government officials.

Taxation is one of the most jealously guarded attributes of national sovereignty, perhaps second only to the maintenance of armed forces. Yet from its inception, income and profits taxation raised questions about national scope and international 
coordination. The scope of state sovereignty seems clear, since the modern state is defined in terms of territory. However, this still leaves room for considerable extension and produces overlap between the actual jurisdiction of states. Thus, taxes on income can be levied when earned and at source, or when received, either by citizens of or residents within the state. States may tax on both these bases, as in fact Britain and some other developed capitalist states have done. ${ }^{8}$

Not surprisingly, as tax rates began to rise early this century, complaints about international double taxation began to be made, most vociferously by those engaged in international business or commerce. They pleaded for equality in the conditions of competition. One of the most vocal in the UK was Vestey family, who built the biggest private fortune in Britain based on combining cold storage and distribution here with access to cheap sources of food abroad, such as eggs from China and beef from Argentina - they later became familiar as owners of the Dewhursts butcher shops, though the group was recently liquidated just. Back at the time of the First World War, the Vestey brothers developed a deep resentment against what they considered to be the unfair double taxation burden created by the British rules of residence. In evidence to the Royal Commission on Income Tax in 1919, Sir William Vestey argued for fairness in taxation of a global business such as his:

"In a business of this nature you cannot say how much is made in one country and how much is made in another. You kill an animal and the product of that animal is sold in 50 different countries. You cannot say how much is made in England and how much is made abroad. ... It is not my object to escape payment of tax. My object is to get equality of taxation with the foreigner, nothing else."

However, he failed to convince either the Royal Commission, or the Prime Minister, Lloyd George, to whom he wrote privately. The official British view was that relief from overlapping taxation would depend on the negotiation of international arrangements, which could take account of the effects on international movements of capital. International negotiations, however, failed to find a comprehensive solution. A diplomatic conference held in 1928 could only agree on the texts of draft treaties, to be used as models for bilateral negotiation between governments, but few treaties were actually concluded during the 1930s.

In the meantime, private wealth-owners and companies devised their own measures. The Vesteys, in particular, resorted to an elaborate international family trust and corporate structure, aimed at reducing their liability to British tax to almost nil. Very briefly, the scheme was for the Union Cold Store company to pay rent for the use of their world-wide assets, allowing most of the global profits to accumulate in a Paris trust, which merely made loans for the personal expenses of the Vestey family in Britain. The scheme eventually resulted in protracted legal battles lasting several decades, in which the Vesteys scored two notable legal victories in the House of Lords. The Vesteys were perhaps exceptional but not unique, and international tax planning developed in the inter-war period as a means of mitigating what wealthy families and businesses considered to be an unfair burden, due to the inadequate coordination between states of their national tax jurisdictions. These arrangements 
were devised by a growing new breed of cosmopolitan business lawyers (Picciotto 1995).

After 1945, there was a rapid growth of a network of tax treaties, based on the model developed from the pre-war drafts. These treaty arrangements were typical of many developed since the late 19 th century to reconcile national state sovereignty with the development of the world market. No attempt was made to establish a common regulatory regime - each state remained formally free to determine the scope and incidence of its own taxes. However, premised on their mutual interest to stimulate flows of investment between them, the states agreed an allocation of tax jurisdiction.

International investment did indeed gather momentum, but it mainly took the form of direct investment by corporate groups (or transnational corporations: TNCs). Direct investment by TNCs often entailed little actual outflow of money-capital, but relied on local borrowing, capitalisation of intangible assets, and reinvestment of earnings. There were still complaints about the inadequacy of coordination of tax jurisdiction, but the firms again found their own solutions through international tax planning. Since these firms were organised as international corporate groups, it was relatively easy to route investments through intermediate companies incorporated in convenient jurisdictions. This enabled returns on such investment to be accumulated and reinvested free of home-country tax, unless and until they were actually needed back home, for example to pay dividends. Initially, the home country tax authorities overlooked or tolerated these arrangements, provided they fell within acceptable limits, which were negotiated relatively informally. However, as the patterns became routinised and much larger in scale, more formal regulations were introduced by the main capital-exporting countries asserting the right to tax the so-called 'passive' income accumulated in intermediary companies in low-tax jurisdictions, or 'tax havens'.

The internationally-integrated character of TNCs tended to reveal the inadequacy of international tax arrangements based on allocating jurisdictional rights. This was especially shown in the politicisation of transfer pricing. This issue had already been identified by specialists in the 1930s, but surfaced again more publicly in the 1960s. Where business is carried on in an integrated way by a corporate group through branches or subsidiaries in different countries, there is often a high flow of transfers between them, involving anything from component parts or sub-assemblies to intellectual property rights. Since the 1960s there has been a growing awareness that a high proportion of international trade between countries, now amounting to as much as 30 or $40 \%$, actually consists of internal sales within a single international corporate group, such as Ford or Hoffmann LaRoche. The prices fixed for such transfers obviously have a direct bearing on the profits shown in the national accounts of the different affiliates. Legal powers were introduced, for example in the UK as far back as 1915, allowing the national tax authorities to readjust the company's accounts, if they considered that such prices had been manipulated in order to reduce national tax liability.

Where related companies operate within a single state, the obvious solution is to permit or require them to submit consolidated accounts. This is rather difficult internationally without severely compromising national sovereignty. The adoption of 
a global unitary approach to internationally-integrated businesses would require at least a comprehensive multilateral agreement between states, defining when a business can be considered unitary, common accounting rules, and a common formula for apportioning its taxable profits. Even within the EU such a comprehensive approach is not on the immediate agenda.

The solution adopted, which was first agreed internationally in 1935, is the so-called Arm's Length rule. This enables the subsidiaries of TNCs to be assessed on the basis of their own separate accounts by each state, with intrafirm prices within the group being fixed at what would have been paid had the related entities been independent parties negotiating through the market, at arm's length. It was understood from the beginning that there was a good deal of artificiality in this approach, since the whole raison d'être of an internationally-integrated firm is that this integration or internalisation gives it competitive advantages, so that comparable transactions between independent entities would not be available. This principle was adopted as a second-best solution, but national tax authorities understood from the start that Arm's Length would only defer the problem, since any adjustments to transfer prices by one tax authority would be likely to create double taxation unless the authority responsible for taxation of the related firm were willing to accept a 'corresponding adjustment' to the latter firm's accounts. Thus, the German report to the League of Nations inquiry on the matter in 1932 emphasised that national fiscal authorities would have to give each other reciprocal assistance to facilitate allocation, and anticipated that internationally-agreed general principles would gradually emerge.

This rather prescient insight has however taken some decades to be proved accurate. The transfer pricing question lurked in the shadows until it was illuminated by the growing political concern about the power of 'the multinationals' during the 1960s and 1970s. In response, the tax authorities of the main OECD countries have been trying for two decades to coordinate their approach to transfer price adjustments. They adopted a generally slow and careful bureaucratic approach, but it has been given a good deal more urgency by the growing fiscal crisis of the national state, which I have already mentioned. The revolt of the middle-class taxpayer has led politicians to denounce tax-dodgers, and has obliged the Revenue authorities to step up national enforcement. In the USA for example, a 1990 Congressional study attacked 'unfair competition' from subsidiaries in the USA of Japanese and European firms, claiming that 36 Pacific-rim and European-based multinationals with more than $\$ 35$ billion in retail sales in the US in 1986 paid little or no US income tax. ${ }^{9}$

The stepping up of US IRS enforcement against TNCs has inevitably led to increased efforts in other countries. Notably Japan's National Tax Administration activated its transfer price enforcement from 1993, resulting in tax assessments on foreign companies such as Coca-Cola of $\$ 145 \mathrm{~m}$, Hoechst of $\$ 24.9 \mathrm{~m}$, and Procter \& Gamble of $\$ 9.5 \mathrm{~m}$. Specialist commentators pointed out that the Coca-Cola adjustment was almost exactly the same as the amount the Japanese had been forced to give up following a controversial adjustment made by the American IRS on Nissan (Baik and Patton, 1995, 218). Here in Britain also, the Inland Revenue in November 1995 called a press conference to draw attention to figures in its annual report for 1994-5, which showed that its increased compliance effort had netted over £6billion, the equivalent of $3.5 \mathrm{p}$ on the basic rate of income tax. Two-thirds of this apparently 
came from adjustments on companies, apparently including a transfer price adjustment on one single company, which was not identified, to recover $£ 1,638 \mathrm{~m}$. (Kelly 1995).

In fact, although the national tax authorities had long known that transfer price adjustments could be an extremely cost-effective area of 'compliance' work, they were equally aware that the weakness of the international criteria could lead to titfor-tat or beggar-my-neighbour competition between states. ${ }^{10}$ Thus, the increased pressure on the national state as expressed in its fiscal crisis has also exposed the weaknesses of the international coordination arrangements.

If there is now an 'international tax régime' for TNCs, it consists of an inadequately coordinated, mainly administrative process of negotiation between managers or professionals representing firms and national tax officials of the major developed countries. ${ }^{11}$ None of the participants seem to consider it either desirable or politically feasible to envisage a more comprehensive global approach. Just such an approach had been considered, but largely rejected, in the 1930s: so-called worldwide unitary taxation. This would be mean consolidating the accounts of all the affiliates within a transnational corporate group, rather than treating them as separate entities, and then allocating the profit between the various business by formula. However, it would increase the risk of 'double taxation' unless there could be broad international agreement both on the basis for consolidation and on the formula for the apportionment of profits between jurisdictions. Tax specialists have considered it impossible to reach political agreement on these difficult political issues, so unitary taxation has been strongly resisted. On the other hand, there is clearly a need for a stronger basis of legitimacy and even an institutional framework to counteract the arbitrariness of the present process, especially when such large sums are involved. In fact, business has argued since the 1930s that there should be a right of access to international arbitration of double taxation claims (especially transfer price adjustments), but governments have long rejected this as involving a limitation on their sovereignty. The possibility of such a procedure has finally been conceded in some recent tax treaties, and there is now a multilateral treaty between the EU states, although the arrangements are secretive and likely to be rarely invoked.

As with taxation, so with many other areas of business and economic activity; state sovereignty has become unravelled, as both its internal and international aspects have come under pressure. Another example, which I do not have space to discuss here in any detail, is intellectual property, for example copyright in literary or artistic works, or patents in technology. As with income taxation, legal protection of rights to innovation developed along broadly similar lines in the main capitalist countries in the second half of the 19th century; and due to the interdependent nature of national economies, intellectual property laws were loosely coordinated through international treaties. ${ }^{12}$ As the process of commodification both of science and culture has become much more complex in recent years, the mediation of control over this process through intellectual property rights has become much more contested; and as with taxation, this has caused a breakdown both of national systems of legitimation and of the international arrangements through which they have been coordinated. Even if the granting of monopoly rights is economically justifiable, is it morally justified to give such protection, for example for the genetically-engineered onco-mouse, or for a 
rare DNA pattern identified among particular ethnic groups? A computer software firm may be considered entitled to some economic reward for its efforts in compiling a new programme; but should this be treated as a literary or artistic work and therefore entitled to copyright, which gives protection for a very long time - the author's life plus 50 or 70 years? And should copyright also protect the design features such as the menu structure of a program, a claim just rejected by an even 4-4 split among the Justices of the US Supreme Court in the dispute between Lotus and Borland over their rival spreadsheets? These are difficult enough questions for a national regulatory system to resolve, yet the world market scale of the activities calls for global solutions.

\section{Global GovernanCE AND COSMOPOLITAN LEgalism}

I hope that these examples help to illuminate some of the issues posed by what is now referred to as global governance. The growth of the world market and capital accumulation has created increasingly difficult problems of regulation both at national level and of international coordination. The internal fragmentation of the liberal state has been matched by the growth of an increasingly dense network of international coordination arrangements between states. This is not a matter of a sudden collapse of the national state in the face of pressures from the world market. Rather, they are two aspects of the same process, and share much in common. I would like, in this final section, briefly to discuss two features of this process in particular: first, the transformation of politics and the professionalisation of governance, and second the increasingly ubiquitous role of law, and especially in the global context, the implications of the call for a new cosmopolitan legalism.

The first feature, I think, is attributable to the increasingly wide gap between popular social and political expectations and pressures and the capacity of traditional political structures, especially the liberal democratic state, to deliver consensus. Within the state, an increasing cynicism about and disillusionment with parliamentary politics has been accompanied by a broad politicisation of everyday life. Lifestyle issues previously considered private have become politicised, through the growth of gender and sexual politics, and more generally in the highlighting of issues such as the bearing and raising of children; while conversely, public political questions have been personalised, so that a person's stance towards a foreign government or global issues such as ecology are reflected in the contents of their shopping basket. However, this is a fragmented and dispersed politics, which only sporadically takes form as collective action, although it is in some ways routinised and professionalised through pressure groups and social action organisations. It is hardly surprising that the traditional parliamentary and electoral system finds it hard to respond adequately to this widespread politicisation. The corollary, however, can be a growing sense of powerlessness, as popular concerns seem unable to make much impact on public decision-making.

Internationally, it is easier to identify what is generally termed the 'democratic deficit' of regional and global arenas. There again, however, I would say that this is due to the politicisation of the international sphere and the spotlight that this has thrown on the weaknesses of international political processes. The same broadening of political consciousness that has transformed national politics has also broken into the 
international arena, as issues such as world poverty, environmental protection, and health and disease, have become the focus of popular concern in much more direct ways due to the immediacy of global media and communication. As a result, a wide range of activists and organisations have invaded institutions and fields formerly dominated by state officials and diplomats. Non-governmental organisations may not have much power, but they can have considerable influence, and are to some extent being incorporated into global governance arrangements (Lipschutz 1992, Willetts 1990). ${ }^{13}$

The overall effect is I think of a dispersal of politics away from the centralising channels which lead to the state, and into a variety of specific functional arenas. This appears to allow particular issues to be regulated in a depoliticised, technocratic manner, by managers or professionals who are directly accountable to their 'customers'. The role of the state can, it seems, be reduced to a bare minimum, which is to provide legitimate coercion and to manage money (though even these could be delegated, as prisons can be contracted out to security firms, and monetary policy to professional central bankers).

Yet, curiously, as the state appears to be withering away, it is being reinvented. The purists who advocate a minimalist role for the state, paradoxically demand that it be a strong state, and be based on strict national affiliation and identification. Others accept that there are limits to the market, and therefore argue for state intervention to make rules which govern market transactions, or to remove some areas from the market, whether to remedy market 'imperfections', provide a 'social dimension', or heal social divisions. While political philosophers and practitioners debate the conceptual foundations (the social market, communitarianism, the stakeholder society), the means of implementation lie readily to hand: the rule of law.

Or rather, rules of law, since the appealing advantages of law lie in its pluralism and flexibility, as I have argued above. These are the features which appear to make law apt to handle the increasing problems of diversity and interaction created by the fragmentation which I have described. The difficulty however, as I have also pointed out, is that law can provide at best a set of techniques, or a procedural framework, within and through which social power relations must be played out. Indeed, to put forward a legal form of regulation to govern an issue is very often a power-play in itself. Much can therefore be learned about the changing dynamics of social power by a careful analysis of the changing forms of law, and the processes of their creation. But law cannot be relied upon by itself to transform relations of power.

It is perhaps not surprising that the widest gap between the expectations that may be aroused by resort to law and its capacity to satisfy them is at the level of international law. Here, as I have tried to show, the dilemmas about the nature of the state and its sovereignty are most acute. There is no shortage of examples of issues that are nowadays identified as requiring global solutions, generally better known than the illustrations from business regulation that I have discussed here. From Stockholm and Rio to New Delhi and Cairo, however, the outcome is generally a grandiose statement of pious generalities, which leaving it up to the state and inter-state negotiations to strike the necessary balance between economic imperatives and political acceptability. ${ }^{14}$ 
Yet, as I have also tried to show, the state and its sovereignty are also an increasingly inadequate basis for resolving governance issues. Hence more weight is put on law and legal institutions, which I doubt they are strong enough to bear. Let me give you a couple more current examples, to conclude. One is Bosnia-Hercegovina, an old state recently reborn and now refounded under a new Constitution, agreed in Dayton Ohio, signed in Paris, the text of which was made available almost immediately on the World Wide Web. Drawn up by experts in the US State Department, it allows for two 'national entities' each with its own constitution and an unprecedented degree of autonomy, although within a formally unitary state. The armed force necessary to bring the situation on the ground into rough approximation with this blueprint, is under US leadership, NATO coordination, and authorised by a Security Council resolution, but has a strict 12-month timetable. What is being relied upon to make this highly innovative structure work? The most advanced machinery of human rights law ever conceived, with a Human Rights Ombudsman, and an international Human Rights Tribunal including judges appointed by Council of Europe states, to be resident in Sarajevo; together with an International War Crimes Tribunal sitting at The Hague. We can only wish it every success.

If that is an example of an international effort to reconstitute a national sovereign state, the contrasting example must be the European Union. Here, law has substituted for the failure or inability to decide whether or how to transcend the national state. The key integrating force of the EEC, now the EU, has been the European Court of Justice, which has transformed the Treaty of Rome and its related conventions into a 'constitution for Europe'. ${ }^{15}$ Yet this has been 'constitutionalism without a constitution'. The ECJ has been driven forward not only by the fervour of its judges, with the support of the broader network of European lawyers including, very importantly, national court judges, but also by the logic of the economic law it is required to apply. Yet it is now clear that both the fervour and this logic have reached their limits. Clearly, Europe now needs an institutional transformation, and not merely a legal underpinning, to coordinate and sustain the regulatory framework of the Single Market. Of course this does not mean a centralised state, and a range of possibilities can easily be devised by lawyers, whether of a federal or confederal character. Although this should be central to the agenda of the Inter-Governmental Conference which started in March 1996, there seems to be little political basis even to discuss the issues involved.

So of one thing we can be sure: that there will be increased opportunities for creative work for European lawyers -- as well as Pan-Asian, Inter-American, international, and even cosmopolitan lawyers. This work is inflected by the perspectives and concerns dominant within the private and public institutions and networks of international big business which bestride the globe. However, these perspectives are far from being as homogeneous, internally consistent, or rational as they might appear. Even within the heart of these citadels struggles are being waged to combine the relentless drive for economic efficiency with a renewed morality taking into account human rights, and the social and ecological effects of business activities. ${ }^{16}$ Furthermore, many others have also had to learn to operate in this new world of intersecting jurisdictions, ranging from social movements, labour and consumer organisations, to migrant workers and street traders. ${ }^{17}$ Hence, we should remember that these opportunities are created by the increasing social conflicts and complexities 
that have put pressure on both national and international state structures, and that at best the law and lawyers can mediate -- perhaps moderate? -- those tensions. Adequate solutions require a more combined effort and, in particular, new mechanisms of political accountability.

1 This is a slightly revised version of my inaugural lecture at Lancaster University, delivered on 31st January 1996. Although I have omitted the anecdotal reminiscences, some of the personal flavour still remains, not as self-indulgence, but to retain the element of reflexiveness which I think has an importance beyond the particular nature of the occasion for which this piece was written. That also accounts for the breadth of issues covered in an all-too short compass. I am particularly grateful to Catherine Hoskyns for her help in preparing this lecture. I am also grateful to Alan Norrie, Peter Fitzpatrick, and two anonymous reviewers for helpful comments.

2 It is frequently pointed out that although trade and international investment have grown faster than GDP in the 1970s and 1980s, the degree of openness and integration in the world economy has merely returned, in quantitative terms, to the pre-1913 period: see e.g. Hirst and Thompson 1996, 26ff; Krugman 1994, 258ff. A similar argument has been made in relation to other measures of global interaction by Thomson and Krasner 1989. Although there are quantitative counterarguments, the globalisation debate is more cogent when it focuses on the qualitative changes in the nature of social and cultural interactions (e.g. Featherstone 1990).

3 An excellent account, combining theoretical analysis with historical exegesis, has recently been provided by Justin Rosenberg (1994).

${ }^{4}$ Thus 'pluralist' perspectives, which stress the multiplicity of interacting legal orders, usually accept that state law claims a dominant position (e.g. Fitzpatrick 1984), although that position may be seen as contested. It has also been argued that the increasing 'porosity' of legal orders has created a new 'interlegality' amounting to a transition towards postmodern law: Santos 1987. For a wide-ranging discussion of the effects of globalisation on the legal field see Santos 1995, esp. ch.4.

5 Thus, Wolfram Hanrieder has argued that 'it is not a new type of international politics which is "dissolving" the traditional nation-state but a new nation-state which is "dissolving" traditional international politics' (Hanrieder 1978, 147); but it would be better to say that there is a process of interaction.

6 For a discussion of the particular role of lawyers in constructing an international regulatory arena see Dezalay 1996.

7 Although an income tax was introduced in Britain during the Napoleonic Wars, and was reintroduced after the repeal of the Corn laws, it never produced more than $15 \%$ of government revenues during the 19th century. Increased spending during the Boer War led to pressures for a graduated rather than a flat-rate tax, and a super-tax was introduced by Lloyd George's 'people's budget' of 1909, which took effect only after a constitutional conflict with the House of Lords. In the US, it was only after ratification of the 16th Amendment to the Constitution in 1913 that federal taxation could shift from import duties to a graduated individual income tax, and the 1909 'excise' tax on corporations was redesignated a tax on corporate profits in 1917. In France, despite several attempts after 1871, a general personal income tax was introduced only in 1914, followed in 1917 by schedular taxes on other types of revenue.

8 The British claim to tax both the worldwide income of UK residents, and income earned in the UK even by foreign residents, was justified on the basis of territoriality: 'either that from which the taxable income is derived must be situated in the UK, or the person whose income is to be taxed must be resident there' (Lord Herschell, in Colquhoun v. Brooks, (1899) 14 App. Cas. 493, at 499). Yet it clearly produces overlapping claims to tax which may be regarded as 'extraterritorial'. 
9 This has also involved a shift in US concerns: whereas in the 1970s its enforcement effort focused mainly on combating avoidance by US TNCs of tax on their overseas earnings, with the growth of inward investment attention shifted to avoidance of US taxes by foreign TNCs.

10 A German official stated in 1986 stated that he had feared for two decades that there would be 'a general open clash between tax authorities in the field of arm's length pricing' (Menck, 1986)..

11 Developing countries are largely excluded from international cooperation arrangements. In any case, they themselves are reluctant to create disincentives for inward investment through high taxes on profits. Although corporate taxes are often a high proportion of state revenues in such countries; this is in many cases due to taxation of natural resource extraction, which is more properly a 'rent' than a tax on income from capital, although it has usually been formulated as an income tax to enable TNCs to credit the foreign taxes paid against their home country liability.

12 In the case of intellectual property, an international campaign to protect the rights of authors and inventors led to the establishment of the Paris and Berne multilateral Unions of 1883 and 1886; however, these provided very loose coordination, as they made little attempt to harmonise the substance of the legal protection to be provided, and only partial coverage (e.g., the USA did not ratify the Berne Convention until 1988): see further Picciotto 1997.

13 Perhaps the most effective and long-running single-issue activist group has been IBFAN, the International Baby-Food Action Network (for its origins and role see Chetley 1986), while Greenpeace has been notable for its spectacular, high-risk actions. Coordinated activities by various groups during high-profile international meetings such as the annual IMF/IBRD sessions have helped to put marginalised issues onto the global agenda, and have led those organisations to set up more formal consultative channels to incorporate perspectives projected by activist groups, notably on women and the environment. Nevertheless, such social movements require effective organisation to compensate for their lack of economic power. Labour or trade union organisations, which have a stronger power-base, have been hampered by their bureaucratic structures, and have been reluctant to join forces with other social movements, which they tend to regard as 'unrepresentative', although this may now be changing (see Munck 1988). On the other hand, representatives of business organisations tend to get a more respectful hearing, and even formal standing, in global forums, in view of the economic power they wield. Thus, TNCs have been given standing under the complaints procedure of ch.11b of the NAFTA (North Atlantic Free Trade Area), and DeAnn Julius has argued that this should be extended to the important dispute-settlement procedure of the World Trade Organisation, although she sees no need for similar access to be given to NGOs which might have relevant interests to represent, such as those of consumers, or the environment (Julius 1994).

14 For example, the principle of 'sustainable development' in the Rio Declaration leaves the balance between economic development and environmental protection to be struck by national states, or by international negotiations.

15 Originally coined by an academic (Stein 1981), the phrase was taken up by a judge of the Court (Mancini 1989). Many now argue that the 'neo-functionalist project' (Burley and Mattli 1993) of integration through law has reached the limits of its legitimacy

16 I use the term 'renewed' advisedly, as a reminder that the emergence of industrial capitalism in the 19th century also involved such struggles, and that the Anita Roddicks of today have their antecedents, from Robert Owen to Josiah Wedgewood and a whole range of other paternalist and philanthropic capitalists.

17 Thus, Rosemary Coombe has pointed to the 'proliferation of new legalities at the intersection of legal cultures and legal consciousness' (Coombe 1995, 797), and has analysed the example of Songhay traders from West Africa selling counterfeit Malcolm X memorabilia in Manhattan, as an 
example of the "multiple frames of cultural reference from which an "interjuridical" consciousness may be forged' (ibid.,806). 


\section{BIBLIOGRAPHY}

Baik, Sunghak Andrew, and Andrew Patton. 1995. "Japan Steps up Transfer Price Adjustment: Joins the APA Fray", Tax Notes International, 13 November 1995.

Burley, Anne-Marie Slaughter, and Walter Mattli, 1993. "Europe Before the Court: A Political Theory of European Integration," International Organization 47(1): 41-76.

Commission on Global Governance (1995), Our Global Neighbourhood, Oxford, OUP.Crawford, James. 1994. "Democracy and International Law." British Yearbook of International Law LXV:113-133.

Chetley, A. (1986). The Politics of Baby Foods. Successful challenges to an international marketing strategy. London, Pinter.

Coombe, R. J. (1995). “The Cultural Life of Things.” American University Journal of International Law and Policy 10(2): 791-835.

Dezalay, Yves, 1996. "Between the State, Law, and the Market: The Social and Professional Stakes in the Construction and Definition of a Regulatory Arena", ch.2 of W. Bratton, J. McCahery, S. Picciotto, and C. Scott (eds.), International Regulatory Competition and Coordination. Perspectives on Economic Regulation in Europe and the United States. Oxford, The Clarendon Press.

Faundez, Julio (ed.), 1996. Good Government and Law: Legal and Institutional Reform in Developing Countries, London, Macmillan.

Featherstone, Mike (ed.), 1990. Global Culture. Nationalism, Globalisation and Modernity, London, Sage.

Fishman, J. J. (1993). The Transformation of Threadneedle St. The Deregulation and Reregulation of Britian's Financial Services, Durham, N.C., Carolina Academic Press.

Fitzpatrick, Peter. 1984. "Law and Societies," Osgoode Hall Law Journal 22: 115138.

Franck, T. 1992. "The Emerging Right to Democratic Governance.” American Journal of International Law 86:46.

Goldstein, M., D. Folkerts-Landau, et al. (1992). International Capital Markets. Developments, Prospects, and Policy Issues. Washington DC, International Monetary Fund.

Hanrieder, W. F. (1978). "Dissolving International Politics: Reflections on the Nation-State." The American Political Science Review 72(4): 1276-87. 
Held, D. (1995). Democracy and the Global Order. From the Modern State to Cosmopolitan Governance. Cambridge, Polity Press.

Hirst, Paul, and Thompson, Grahame (1996). Globalization in Question. The International Economy and the Possibilities of Governance. Cambridge, Polity Press.

Julius, DeAnn. (1994). "International Direct Investment: Strengthening the Policy Regime", in Peter B Kenen (ed.), Managing the World Economy. Fifty Years after Bretton Woods (1994)

Kapstein, E. B. (1994). Governincg the Global Economy. International Finance and the State, Cambridge, Mass., Harvard U. P.

Kelly, Jim. 1995. "Transfer pricing comes out of the shadows", Financial Times, 23 Nov. 1995.

Knightley, Phillip. 1993. The Rise and Fall of the House of Vestey. London: Warner.

Koskenniemi, M. (1991). "The Future of Statehood." Harvard International Law Journal 32: 397-410.

Krugman, Paul. (1994) Peddling Prosperity. Economic Sense and Nonsense in the Age of Diminished Expectations. Norton, New York.

Lipschutz, R. D. (1992). "Reconstructing World Politics: The Emergence of Global Civil Society." Millenium 21(3): 389-420.

Mancini, G. Federico. 1989. "The Making of a Constitution for Europe." Common Market Law Review 26:595-614.

Menck, T. 1986. "International Taxation: Competent Authorities Share their Concerns", Tax Notes, 11 Aug. 1986, 573

Munck, R. (1988). The New International Labour Studies. An Introduction. London, Zed Press.

Picciotto, Sol. 1992. International Business Taxation. London: Weidenfeld \& Nicolson.

Picciotto, Sol. 1995. "The Construction of International Taxation”, in Y. Dezalay and D. Sugarman (eds.), Professional Competition and Professional Power, London: Routledge.

Picciotto, Sol. 1996. "International Law in a Changing World", ch. 13 of G.P. Wilson (ed.) Frontiers of Legal Scholarship, Chichester, Wiley.

Picciotto, Sol. 1997. "Networks in International Economic Integration". Northwestern University Journal of International Business Law, [complete cite to follow] 
Porter, T. (1993). States, Markets, and Regimes in Global Finance, Basingstoke, Macmillan.

Rosenberg, Justin. 1994. The Empire of Civil Society. A Critique of the Realist Theory of International Relations. London: Verso.

Santos, Boaventura de Sousa. 1987. "Law, a Map of Misreading: Towards a Postmodern Conception of Law," Journal of Law \& Society 14: 279-302.

Santos, Boaventura de Sousa. 1995. Towards a New Common Sense. New York, Routledge.

Stein, Eric. 1981. "Lawyers, Judges, and the Making of a Transnational Constitution," American Journal of International Law 75: 1-27.

Thomson, Janice E. and Krasner, Stephen D. 1989. "Global Transactions and the Consolidation of Sovereignty", in Global Changes and Theoretical Challenges, edited by Ernst-Otto Czempiel and James N. Rosenau, Lexington Mass., Lexington Books.

Willetts, Peter (1990), "Transactions, networks and systems", in Groom, A. J. R. and P. Taylor, Eds. Frameworks for International Cooperation, London, Pinter. 